\title{
Forsker og blogger: \\ - webbloggen som forsknings- og fællesskabsværktøj
}

\author{
Lisbeth Klastrup \\ Adjunkt, konst. institutleder \\ Institut for Digital Æstetik og Kommunikati- \\ on \\ IT Universitetet \\ klastrup@itu.dk \\ http://www.itu.dk/people/klastrup
}

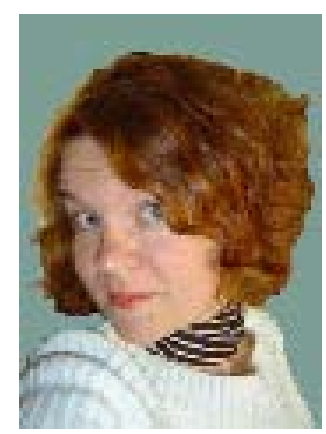

Lisbeth Klastrup er cand. mag. i Litteraturvidensskab og Medievidenskab. Hun skrev ph.d. afhandling ved IT-Universitetet om online-flerbrugerverdener, med fokus på bl.a. kommunikation og interaktion i disse miljøer. Hun forsker fortsat i online-kommunikation, blandt andet weblogs og brugergenererede fortcellinger. Hun har undervist i bl.a. Tekstformidling på Internettet, og er også selv en ivrig online skribent i sin egen weblog, Klastrup's Cataclysms. I 2004 udgav hun med Ida Engholm som medredaktør bogen "Digitale Verdener - de nye mediers cestetik og design".

\section{Baggrund}

I slutningen af 2004 placerede ordbogsproducenten Meriam-Webster ordet “blog” øverst på top-ti listen over årets ord. Dette skyldes ikke mindst ordets gennemslagskraft i forbindelse med samme års amerikanske valgkamp. Men også herhjemme er begrebet “weblog” eller "blog” (på dansk også af og til oversat til "netdagbog”) slået igennem. Ordet og fænomenet er blevet omtalt på både tv, i radio og i den trykte presse og bruges nu ofte uden yderligere forklaring. Der er ingen tvivl om, at f.eks. studerende og folk med en interesse for IT og netmediet har taget genren til sig. Men hvad kan vi som forskere bruge weblogs til?

Denne artikel tager primært udgangspunkt i mine egne personlige erfaringer med at bruge webloggen som et værktøj i mit forskerliv. Samtidig er jeg også som forsker generelt interesseret i webloggen som fænomen, ikke mindst fordi den er et interessant eksempel på, hvordan personlig formidling på nettet i stigende grad sker gennem brug af interaktivt "socialt software”, der gør det muligt for brugeren at skabe og vedligeholde netværk som en integreret del af formidlingen af ens identitet, interesser og viden. Artiklen vil derfor give konkrete eksempler på, hvordan webloggen kan bruges i den daglige forskningspraksis, lige så vel som den mere generelt vil diskutere, hvordan nye netværktøjer er med til at ændre den måde, vi opfatter vores egen rolle som forskere på. Det skal tilføjes, at den praksis-baserede indgangsvinkel til denne artikel også skyldes, at skønt der de senere år er blevet forsket en del i webloggen som mediegenre, er der til dato kun er publiceret meget få videnskabelige artikler om webloggens brug i forskningssammenhæng.

\section{Hvad er en forsker-weblog?}

En weblog defineres generelt som en personlig web-side, der består af små indlæg (“poster”), som er registreret og dateret under hver sin overskrift og i omvendt kronologisk rækkefølge. Stort set alt blog-software inkluderer i dag muligheden for, at læserne kan kommentere et indlæg ved at trykke på det kommentar-link, der findes ud for hvert indlæg. Desuden er der en arkiv-funktion, der gør det muligt for læserne at gå tilbage og læse gamle indlæg, typisk på 
måneds- eller ugebasis. Mange ser kommentar-funktionen som en meget væsentlig del af bloggen som genre - den skaber mulighed for konkret og umiddelbar interaktion med bloggens læsere.

Der findes mange måder at bruge en blog på. En af de tidlige pionerer inden for området, Rebecca Blood (2002), skelner f.eks. mellem brug af bloggen som:

- en logbog/dagbog,

- en notesbog, eller

- et informationsfilter.

I praksis ser man ofte alle tre funktioner integreret i én blog. Forsker-bloggen vil jeg definere som en weblog, der i sit indhold primært fokuserer på skribentens forskningsområde og forskningsinteresser. Den kan både fungere som forskerens dagbog undervejs i et projekt; som en notesbog, hvor forskeren fastholder sine ideer og tanker; og som et sted, hvor forskeren filtrerer og samler relevant information i forbindelse med et konkret forskningsprojekt. På mange måder kan den derfor ses som en forlængelse af de praksisser og arbejdsmetoder, de fleste forskere hyppigt benytter sig af. Mortensen og Walker påpeger da også, at der er en naturlig sammenhæng mellem den akademiske forskning og bloggen som formidlingsgenre:

To blog is an activity similar in many ways to the work of the researcher. A weblogger filters a mass of information, choosing the items that interest her or that are relevant to her chosen topic, commenting upon them, demonstrating connections between them and analysing them. (Mortensen \& Walker: 250)

Det er vigtigt at understrege, at et væsentligt kendetegn ved bloggen er dens personlige indgangsvinkel: en forskerblog ville ikke være en blog, hvis man ikke også fik indsigt i den person, der står bag bloggen. Samtidig er dens fokus forskeren og forskningen, ikke det private og personlige liv. Man kan således sagtens finde forskere, der både skriver en forsknings-blog og personlige blogs om helt andre interesser end de forskningsmæssige.

I det følgende vil jeg præsentere de måder, jeg selv har brugt bloggen på som forsker i de år, der er gået, siden jeg i februar 2001 startede min første blog. Ud over at benytte dette som en illustration af de mange måder, man som forsker kan bruge bloggen på, er det samtidig også historien om, hvordan jeg i stigende grad er kommet til at definere mig selv som "blogger" i lige så høj grad som forsker - eller rettere, som en forsker, der også er defineret ved det faktum, at jeg blogger. Jeg er blevet en forsker, der i høj grad vedligeholder og udvider sit netværk ved hjælp af bloggen.

\section{Bloggens forskellige brugsformer}

\section{Bloggen som åben notesbog}

I 2001 skrev en norsk kollega til mig, at hun havde startet noget, der hed en "blog", og hun opfordrede mig til at prøve. Jeg klikkede mig ind på den web-adresse, hun havde opgivet, og fandt her en masse indlæg, der kommenterede spændende web-steder, hun havde fundet på nettet. Da der her var links og artikler, jeg selv kunne have glæde af, slog det mig straks, at her var måske det værktøj, jeg et stykke tid selv havde søgt. Et værktøj, der gjorde det muligt for mig kort at kommentere og gemme en web-adresse eller web-artikel uden at risikere, at de forsvandt i den efterhånden helt uoverskuelige mængde af "netbogmærker”, jeg som led i mit ph.d.-projekt havde samlet - samtidig med, at jeg her så et middel til at dele mine "netfund" med ligesindede kolleger, der ligesom jeg sad ret isoleret rundt omkring i Norden og kæmpe- 
de med at komme ud i så mange afkroge af nettet som muligt i forbindelse med deres forskning i nye medier. Samtidig så jeg bloggen som en mulighed for at øve mig i at formulere og indfange mine tanker på engelsk, det sprog, jeg vidste, at min afhandling skulle skrives på. Jeg opdagede hurtigt, at der ikke var langt mellem at tænke og blogge, hvilket bloggerne også understregede i etnografen Bonnie Nardis undersøgelse af, hvorfor folk blogger:

Alan observed that once having started a blog, it "forced" him to keep writing, a discipline he deemed important for his work. He said, "I am one of those people for whom writing and thinking are basically synonymous." Evan, a graduate student in genetics, echoed this thought in saying he liked blogging because it was "thinking by writing." He said he often reacted to what he read in the news or scholarly journals and felt a need to see if he really had anything to say about topics that piqued or intrigued him. Writing in the blog allowed him to test his ideas through the act of writing. (Nardi et al : 9)

Den daglige øvelse i at formulere sine tanker og ideer på en forståelig og præcis måde, der også tager hensyn til web- og blogmediets form, er en effektiv måde at træne sig i at formulere og kategorisere ideer, mens man får dem. Blog-genren er kendetegnet ved sin umiddelbarhed, og modsat den traditionelle akademiske formidlingsform, hvor det forventes, at ideerne er tænkt til ende og færdigpolerede, før de præsenteres for et publikum, er dette en formidlingsform, hvor det er udbredt accepteret, at man præsenterer sine tanker, mens de stadig er "work in progress".

Når man skriver til en blog, er det en konvention, at man giver sine indlæg en overskrift, da læseren gennem dem hurtigt kan orientere sig om en weblogs aktuelle indhold. Visse former for blogsoftware (som f.eks. Movable Type og Wordpress) giver endvidere mulighed for, at ens indlæg kan kategoriseres og ordnes efter tema. Det at blogge sine tanker er derfor ikke kun en proces, hvor man blot nedfælder ideer og indtryk. Det er også en proces, hvor man tvinges til at tænke og præsentere dem i en kontekst og generel tematisk sammenhæng, og derved også får en indsigt i en ellers måske ubevidst forskydning af ens interessefelter (figur 1). Rebecca Blood bemærker i sin tidlige introduktion til feltet The Weblog Handbook (2002), at det at skrive en weblog har hjulpet hende til at blive klar over, hvilke områder og emner, hun egentligt har størst interesse for. På samme måde har jeg selv kunnet konstatere, at hvor jeg startede min weblog med et tænkt fokus på online-verdener og computerspil, er der i typen af blog-indlæg og web-adresser, jeg kommenterer, fundet et skred sted i retning af et voksende fokus på online-kommunikation og formidling generelt. 


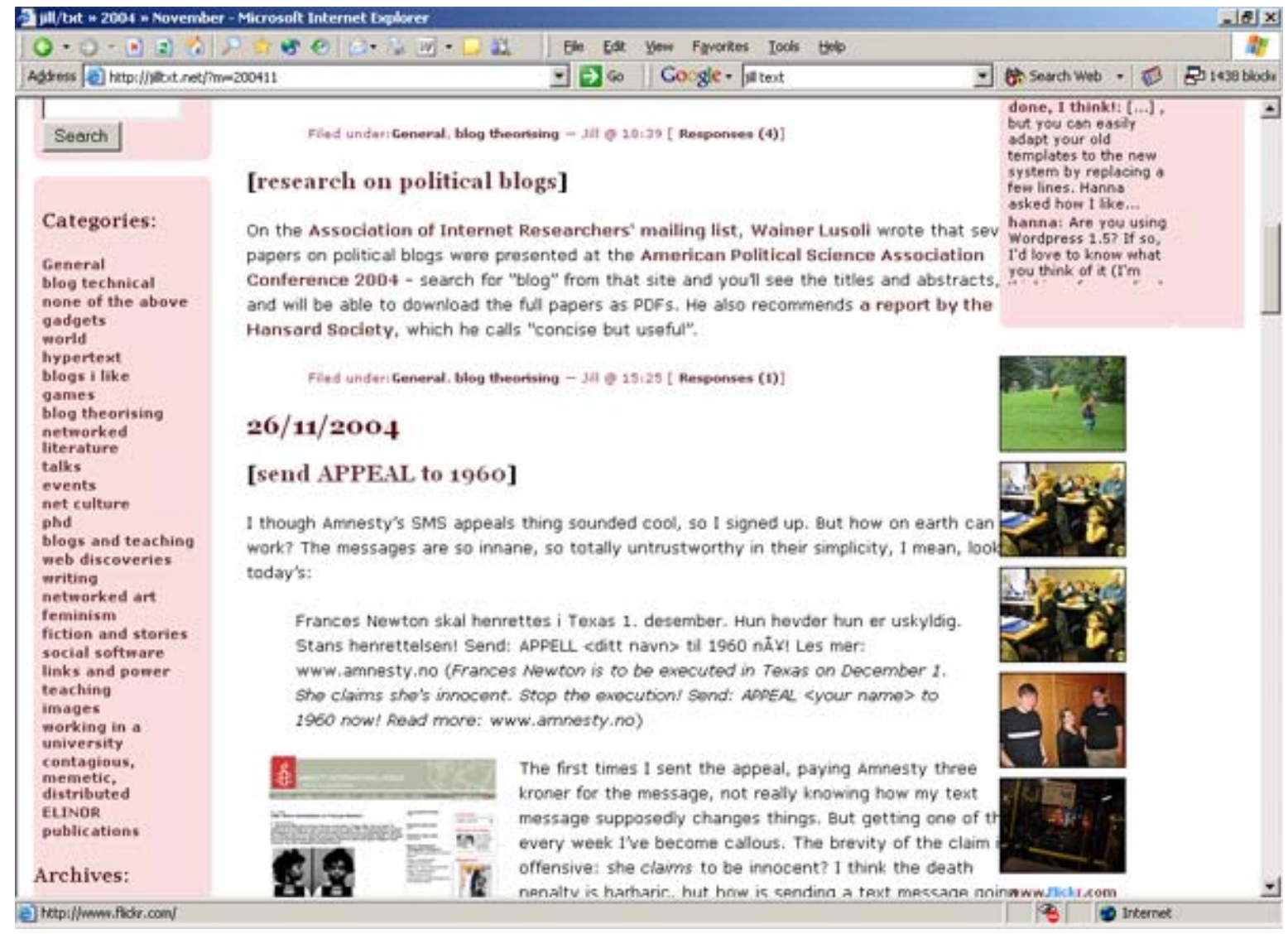

Figur 1. Den norske forsker Jill Walker har gennem læengere tid sorteret sine indlag i forskellige kategorier, der på billedet kan ses i en liste i menuen til venstre. Ved at skimme denne liste får man hurtigt indtryk af, hvor hendes forskningsinteresser ligger. I kraft af kategorilisten, er der reelt to indgange til hendes blog: man kan læse blog-forsiden og få alle indlceg med, eller man kan klikke på et link i kategori-listen og gå direkte til de kategorier og emner, der interesserer en.

\section{Bloggen som netværksskaber og -vedligeholder}

Kort tid efter at jeg havde stiftet bekendtskab med min kollegas blog, fik jeg selv en blog op at stå ved hjælp af blog-servicen blogger.com. I løbet af de næste par måneder startede flere og flere af mine danske og nordiske ph.d.-skrivende kolleger også en blog, og i de næste par år brugte både de og jeg bloggen flittigt til at dele ideer, viden og frustrationer over ph.d.skriveprocessen. Der var tale om kolleger, jeg havde allerede havde mødt ansigt til ansigt, så i tilgift blev bloggen også en måde, hvor vi kunne vedligeholde kontakten med hinanden mellem de årlige konferencer. En amerikansk kollega, Mark Bernstein, begyndte snart at betegne os som "the Scandinavian-flavored media cluster", fordi vi hyppigt refererede og linkede til hinanden i vores blogs (figur 2).

"Someone should take a good look at clustering phenomena in Web logs. For example, consider the interesting and active cluster of media-theory Scandinavian-flavored weblogs from Sjursen, Walker, Klastrup, Frasca, Miles, and others.” (Mark Bernstein Blog, 01.09.2001, http://www.markbernstein.org/September01.html)

Min blog blev hurtigt til et værktøj, jeg dagligt brugte som en slags notesbog, som jeg i tankerne skrev med mine skandinaviske kolleger in mente. Men jeg oplevede også, at jeg med min online blog-tilstedeværelse nåede et publikum, jeg ikke rigtigt på forhånd havde forestillet mig. Det blev pludselig en hel ny oplevelse at deltage i en konference, for når man endeligt 
mødtes ansigt til ansigt, så kommenterede kolleger, jeg aldrig før havde mødt et indlæg, jeg havde skrevet ugen før, eller spurgte til hvordan det gik med den musearm, jeg på bloggen havde beklaget mig så meget over. Samtidig skete det også oftere og oftere, at jeg i forskellige sammenhænge stødte på folk, der kom hen til mig på et seminar eller efter et foredrag og, som en ny måde at komme i kontakt på, erklærede: “Jeg læser din blog!” og derved umiddelbart skabte et bånd mellem os. Jeg modtog også af og til e-mails fra ukendte læsere af bloggen, der havde lyst til at kommentere et indlæg eller gerne ville pege på nogle kilder, jeg ikke var opmærksom på. Alt i alt begyndte det derfor at gå op for mig, at min blog-skrivning ikke bare var en måde at dele annoterede bogmærker med mine venner på, men i høj grad var med til at skabe og udvide det netværk af kolleger, jeg havde. En blog kan være et vigtigt socialt instrument, når man står alene med et forskningsområde på ens egen institution eller kun sjældent har mulighed for at mødes med sine kolleger ansigt til ansigt (figur 3).

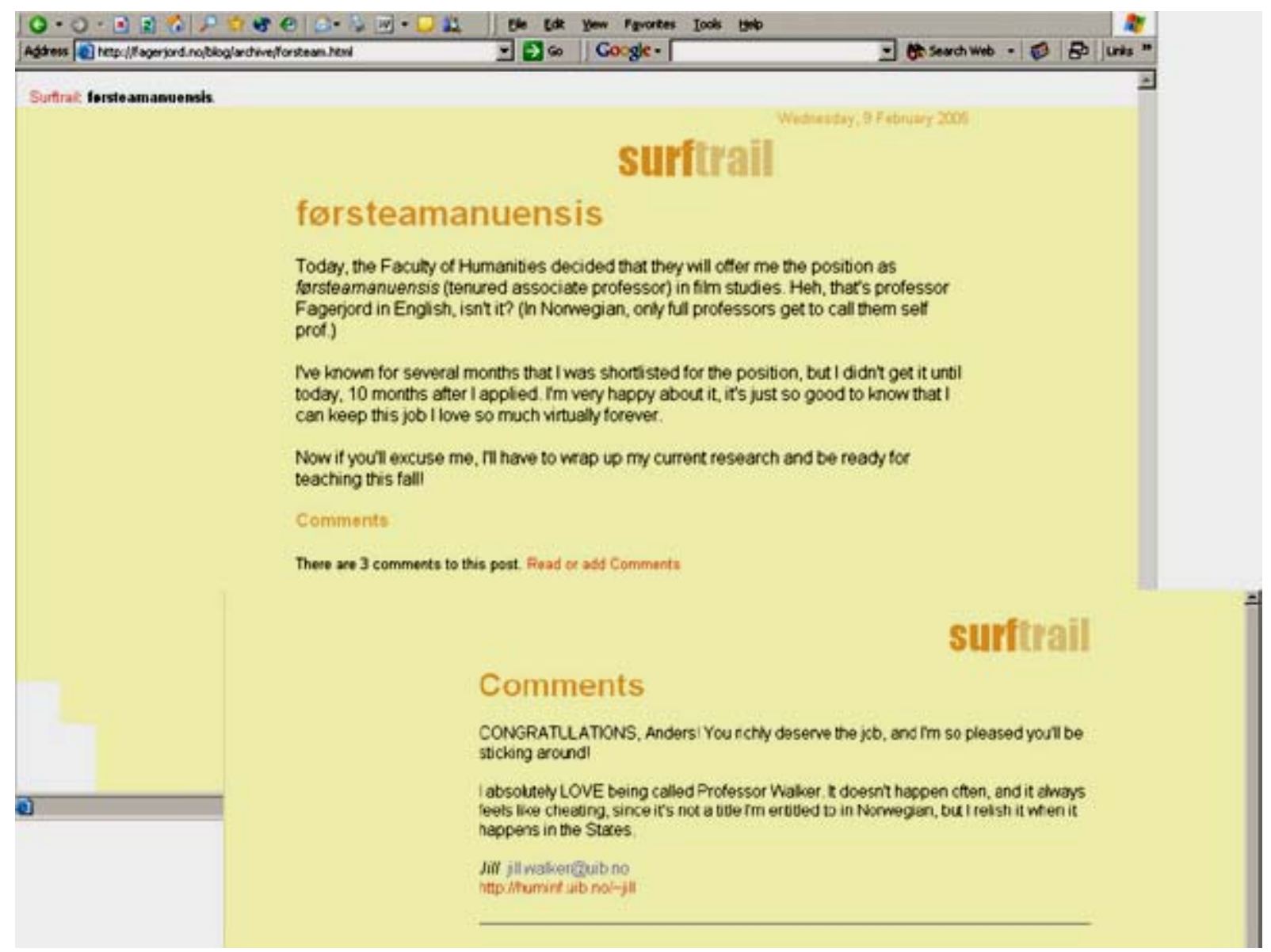

Figur 2. I det tidligere ncevnte ”skandinaviske blogcluster” har bloggen en både social og faglig funktion. De nære kollegers faglige og personlige sejre kommenteres og applauderes af de andre bloggere i netværket. Her lykønsker Jill i Bergen Anders i Oslo med hans nye stilling som førsteamanuensis. 


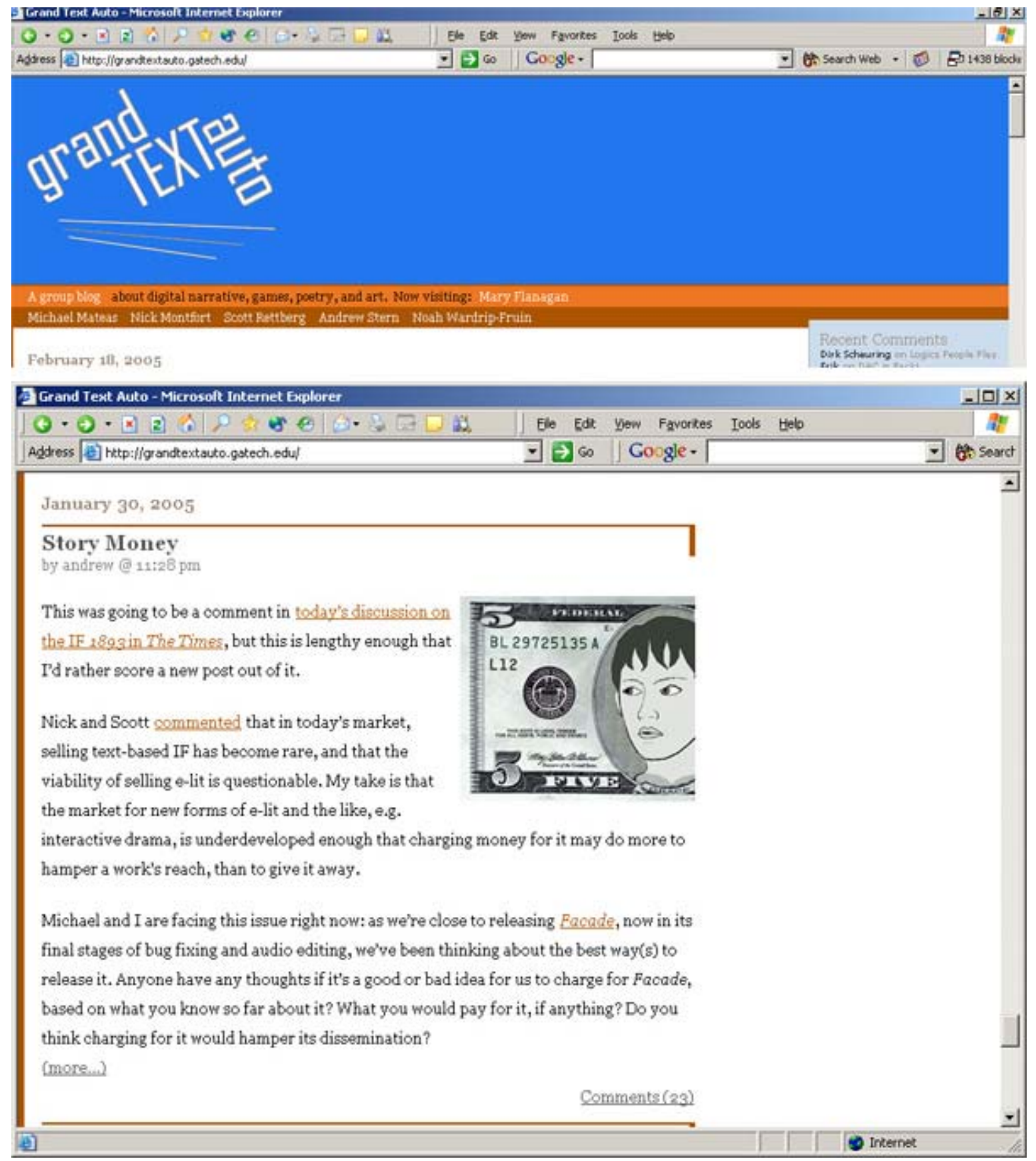

Figur 3. Grandtextauto er en gruppeweblog, skrevet af en lille gruppe forskere rundt omkring i USA, der har en fcelles interesse i "digital narrative, games, poetry and art". Forskere fra hele verden med lignende interesser laser bloggen, og der finder javnligt lange og heftige diskussioner om centrale problemstillinger sted i kommentarerne. Men også et spørgsmål som det, skribenten i det viste indlceg stiller, har genereret en del diskussion - der er langt fra enighed om, hvorvidt folk skal betale for en digital fortcelling, der har kostet forfatterne en masse arbejde, eller om adgangen til vœrket skal væere gratis.

\section{Bloggen som værktøj til kollaborativt samarbejde og vidensdeling}

Da jeg selv havde haft så gode erfaringer med at bruge bloggen som "huskeblok", besluttede jeg i 2003 sammen men kollega at starte en lille gruppe-blog i forbindelse med en fælles artikel, der handlede om selvbiografier og biografier på nettet. Vi uploadede interessante pointer fra artikler, vi hver for sig havde læst; vi linkede til relevante web-steder, vi faldt over og 
kommenterede disse, vi gemte citater, som vi skulle huske at bruge i artiklen, vi noterede pointer, vi skulle huske at have med osv. Da vi endelig skulle skrive artiklen færdig, kunne vi hele tiden bruge bloggen som referenceramme og rodekasse, og vi havde begge en oplevelse af, at vi denne gang havde "husket at få det hele med”. Bloggen eksisterer den dag i dag, og når der er en reference fra den gang, jeg kommer i tanke om, bruger jeg den som en slags opslagsbog (figur 4).

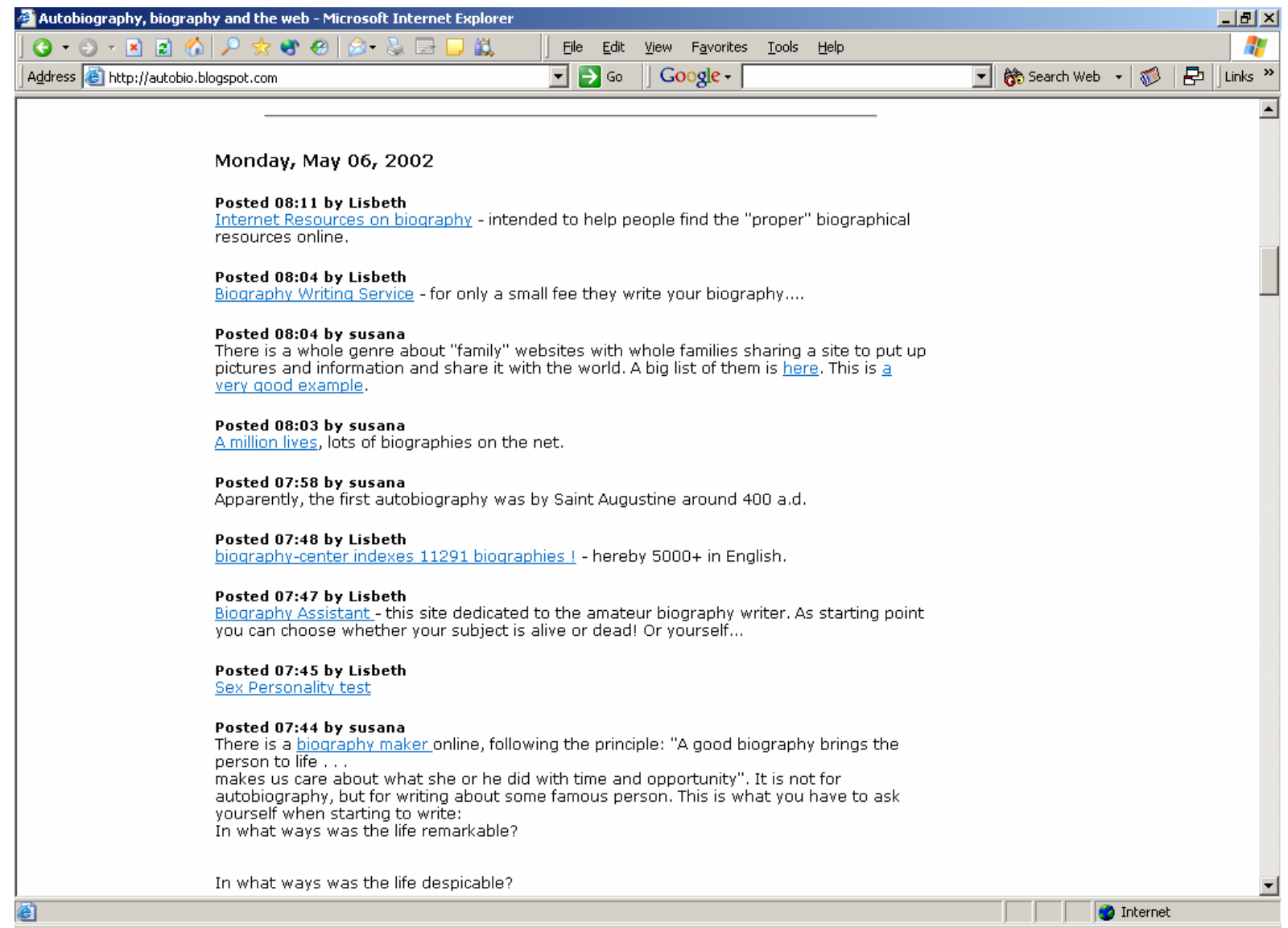

Figur 4. Uddrag fra den weblog, en kollega og jeg brugte som væerktøj i forbindelse med skrivningen af en feelles artikel om autobiografier og biografier på nettet. Indlaggene bestod både af links til relevante websites og værktøjer online, citater fra tekster vi havde last på nettet, opsummering af lesst litteratur, fakta vi skulle huske at have med i artiklen osv. Iscr $i$ perioden op til selve skrivningen af artiklen blev der postet en del.

Det samme gør sig gældende for den gruppe-weblog, jeg for nylig har brugt i samarbejde med nogle forskerkolleger, der er geografisk fordelt over flere steder i landet. Denne gruppe er sammensat af folk med forskellige fagligheder, og bloggen blev i projektets opstartsfase i høj grad brugt til at dele referencer, links og henvisninger til litteratur, personer og projekter, det var vigtigt, at vi alle fik kendskab til. En erfaring, jeg dog også måtte gøre mig i denne forbindelse, var, at så længe der ikke findes nemt brugbare værktøjer til at informere deltagerne i en gruppe-blog om, at den er blevet opdateret, og så længe nogle deltagere føler sig fremmede over for teknologien, kan det være svært at gøre bloggen til et oplagt samlingspunkt, fordi folk ikke naturligt tænker på bloggen som en kommunikationsmulighed og fordi alt for få bruger den jævnligt. Man kan sørge for, at bloggen også gemmes i f.eks. xml-format, for det gør det muligt for brugerne af den at abonnere på de såkaldte "rss-feeds” (RSS= Rich Site Summary), der kan gøre det nemt at finde ud af, om en blog er blevet opdateret eller ej. Det kan ske enten ved hjælp af et særligt stykke software (f.eks. en såkaldt "newsreader), eller ved at anvende online-opsamlende services som Bloglines.com. Vil man følge med i sine kolle- 
gers skriverier på denne måde, kræver det dog, at man som bruger aktivt anvender denne service. Der mangler stadig et gennemtænkt hjælpeprogram, der kan videresende information om en opdateret blog til forskere, der ikke er særlig aktive web-læsere.

\section{Bloggen som blæksprutteindsamler af viden}

Mit seneste forsøg på at udnytte webloggen som forskningsværktøj fandt sted i forbindelse med valgkampen i januar 2005. Da valget blev udskrevet, besluttede jeg at forfølge en interesse, jeg havde længe haft: kunne man ved at studere en særlig gruppe af weblog-brugere sige noget om, hvordan weblog-mediet blev brugt og assimileret i en ren dansk sammenhæng? Studerende er i løbet af de sidste par år begyndt at skrive opgaver og specialer om webloggen, men ingen forskere herhjemme har, så vidt vides, forsket mere dybtgående i det danske weblog-fænomen og den danske weblog-kultur. Valget var en oplagt mulighed for at studere dette fænomen, fordi det hurtigt blev tydeligt, at flere danske politikere havde ladet sig inspirere af den brug af valg-weblogs, der netop havde haft stor betydning i den amerikanske præsidentkampagne, ikke mindst i kraft af Howard Deans succesfulde netbaserede markedsføringsstrategi. Jeg besluttede mig derfor til at prøve at registrere og følge brugen af weblogs i den danske valgkamp, og det syntes oplagt selv at bruge en weblog til at synliggøre dette forskningsprojekt (figur 5). Min egen brug af webloggen som projektformidlingsform viste sig da også følgende at blive en stor succes, ikke mindst fordi jeg meget tidligt var så heldig at få bloggen, Walgblog, omtalt i en artikel i Politiken. I løbet af valgkampen fik både jeg og den specialestuderende, der blev inddraget i projektet, gennem bloggens kommentarfunktion og gennem personlige e-mails mange henvendelser, både fra politikere, webmastere og danske webloggere, der ønskede at gøre os opmærksom på weblogs, vi ikke selv havde opdaget. På den måde fik vi således kendskab til web-dagbøger, vi ikke nødvendigvis selv ville havde fundet, og vi fik etableret en kontakt med mulige interviewemner til den påtænkte opfølgende undersøgelse efter valget. Den heldige annoncering af Walgblog så tidligt i valgkampen gjorde også, at bloggen blev det naturlige referencepunkt for folk, der var interesserede i at læse politiker-weblogs. Det betød, at også flere af de bloggende politikere henviste til den, ligesom bloggen optrådte på flere af de danske blog-metasites som f.eks. overskrift.dk. Det førte til mere trafik til sitet og følgende til endnu flere henvendelser og kommentarer fra læserne. Det er i denne sammenhæng dog vigtigt at gøre opmærksom på, at ønsker man at bruge webloggen som et instrument til at skabe opmærksomhed om et projekt for at få data til det, må man også som forsker være indstillet på at lægge arbejde i at pleje bloggen gennem hyppige opdateringer. Hyppig aktivitet på bloggen er et centralt element i opstarten af den, ikke mindst hvis man fra starten lover sine læsere, at man kan finde aktuel information på den. Opfylder man ikke denne kontrakt med læserne, vil man hurtigt fremstå som utroværdig i de kritiske blog-brugeres øjne. Man skal derfor være indstillet på at lægge en del tid i især opstartsfasen af denne form for blog. 


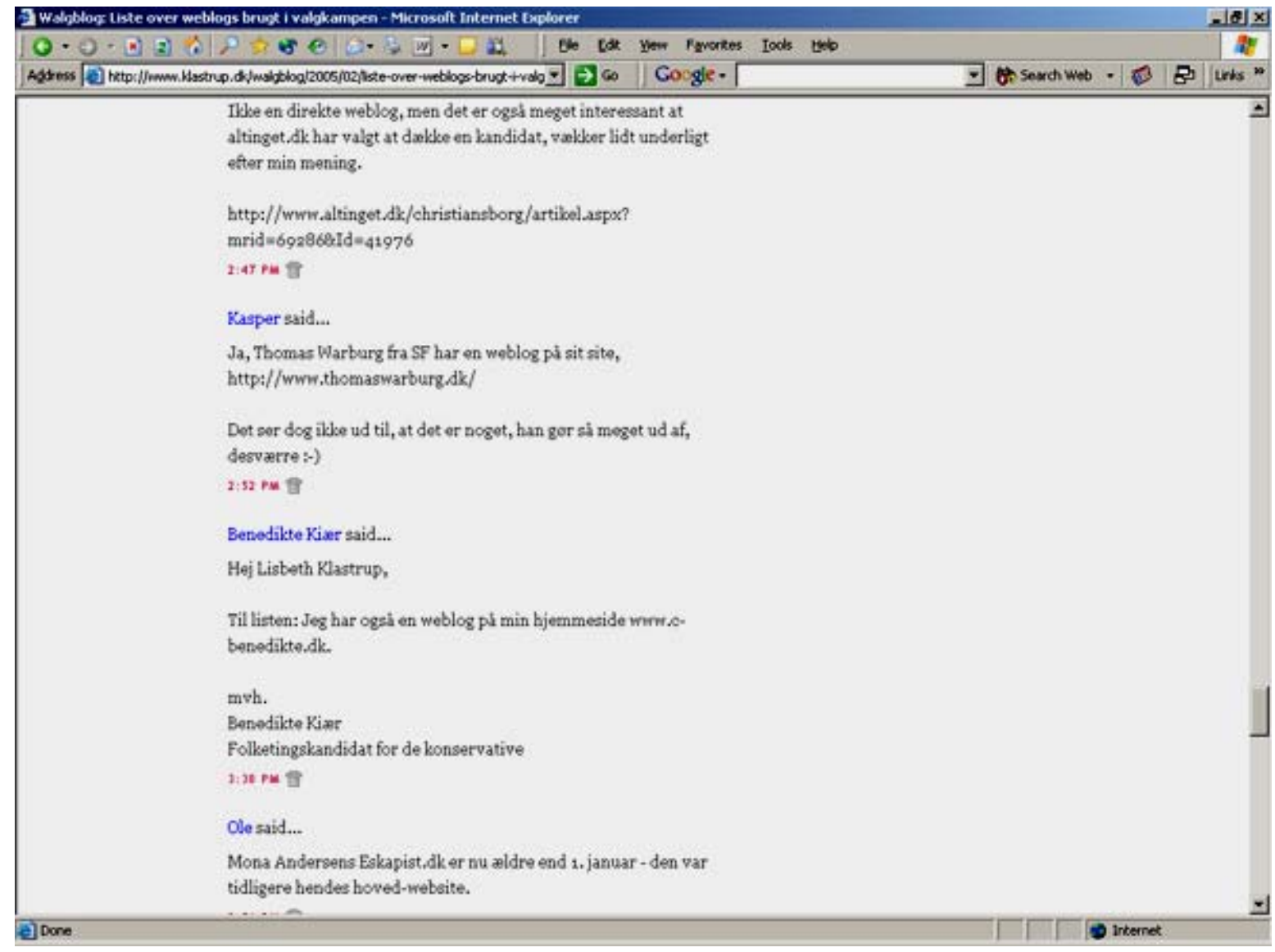

5. Walgblog blev startet som led i en undersøgelse af brugen af weblogs i den danske valgkamp januar-februar 2005. Efter bloggen blev omtalt i Politiken, begyndte folk at bruge kommentarfunktionen til at gøre opmcerksom på blogs, vi havde overset eller til at rette på os, hvis vi havde prcesenteret en blog med forkerte data på vores blogliste.

\section{Hvorfor blogger danskere forskere ikke?}

Den anonyme person bag websitet spontek. $d k$ vedligeholder en side med en stadig aktuel liste over danske weblogs. I januar 2005 var listen på 416 danske weblogs, skrevet af folk bosat i Danmark og på enten engelsk eller dansk. Baseret på denne liste og på mit personlige kendskab til bloggere i det danske forskningslandskab findes der omkring 10 danske akademikere, involveret i forskning, der i dag (januar 2005) blogger eller har blogget. Man kan undre sig over, hvorfor så få danske forskere har taget bloggen til sig som forskningsværktøj, når man tager i betragtning, at mange danskere forskere, også i kraft af landets størrelse, i høj grad orienterer sig mod - og har behov for at relatere sig til - et internationalt netværk af kolleger. Det skyldes sandsynligvis en blanding af mangel på kendskab til mediet, mangel på tid, mangel på lyst og mangel på viden om, hvad man som forsker rent faktisk kan bruge blogværktøjet til. Hertil kommer så eventuelle forbehold over for f.eks. at skrive på engelsk som forudsætning for at nå ud til et større publikum. I denne sammenhæng peger Mortensen og Walker (2003), med en terminologi hentet fra Pierre Bordieu, på, at den manglende lyst til at skrive om og offentliggøre sin egen forskning, også før den er færdig, grundlæggende kan bunde i det faktum, at forskernes viden er deres vigtigste "symbolske kapital”. Angsten for at miste vores mest betydende våben i det akademiske karrieresystem, nemlig vores originale ideer, kan føre til et naturligt forbehold over for at dele disse ideer med andre: 
The current reward system depends on certain formulas of academic publishing that encourage exclusivity and the fear of being robbed of thoughts and ideas. Since the real currency in the trade of academia is originality of thought and imaginative development of theories, there is more to lose than to gain in exposing your own ideas too early. The danger of having thoughts, ideas or questions copied before they have been published is not just a matter of some petty game between jealous professors with too little time on their hands, it's a very real matter of being robbed of the currency which measures academic success. (Mortensen \& Walker: 262)

I samme åndedrag gør Mortensen og Walker dog også opmærksom på, at webloggen faktisk kan tjene som et sted, hvor man som forsker kan "forankre" sine ideer med mulighed for at henvise til publicering på bloggen i tilfælde af, at der skulle opstå tvivl om, hvem der fik ideen først. Det er lykkedes både danske og norske forskere at få et ISSN-nummer på deres blog (se f.eks. http://www.konzack.blogspot.com), hvilket kan ses som en slags blåstempling af bloggen som et officielt anerkendt "publiceret værk”. Blogger man i en gruppe i forbindelse med udviklingen af et forskningsprojekt, er det ligeledes vigtigt at være opmærksom på, at der findes blog-software, der kan gøre det muligt at begrænse læsningen af en blog til et antal udvalgte læsere, således at den, i lighed med andre netbaserede CSCW-systemer, fungerer som et mere traditionelt værktøj til kollaborativt samarbejde. Det er altså muligt, på forskellige måder, at beskytte ens blogtekst.

Samtidig er bloggen en mulighed for at nå et meget bredere forum af læsere end dem, der typisk læser forskningspublikationer. Har man netop publikationer i form af arbejdspapirer, der ikke er klar til eller egner sig til at blive publiceret i et akademisk tidsskrift, er bloggen et oplagt sted at skabe opmærksomhed om disse, og det er et godt forum at få dem dissemineret i. Bloggen som formidlingsværktøj burde derfor også kunne skabe en diskussion om akademiske publiceringskonventioner, og den burde få os til som forskere at overveje, hvilket publikum, det er, vi egentligt vil nå, når vi kommunikerer vores forskning til andre.

\section{Hvorfor burde danske forskere overveje at blogge?}

Som formidlingsform tvinger webloggen os til at gentænke vores forskningspraksisser og vores egen rolle som forskere. Som jeg har prøvet at vise i den ovenstående gennemgang af mine egne erfaringer med genren, giver brugen af bloggen næring til refleksioner over, hvad det er, man egentligt vil som forsker, hvornår man skal publicere, og hvem man skal publicere for og til. Den kan medvirke til at skabe en bevidsthed om ens egen idéudviklingsproces og forskningsmæssige orientering. I tillæg er det at blogge en interessant mulighed for at træne sig i at skrive under andres blikke og i formulere sine ideer forståeligt til andre i en tid, hvor det forventes, at vi stadig oftere skal samarbejde med andre forskere i forskningprojekt-sammenhænge, også på tværs af landegrænser. Bloggen skaber f.eks. mulighed for indgå i og udvikle et socialt netværk og udveksle ideer med ligesindede forskere rundt omkring i verden, når ens eget forskningsområde er marginaliseret i en dansk sammenhæng, og den muliggør videndeling uafhængig af lokalt baserede og dyre "professionelle" softwaresystemer. Endelig giver bloggen, både i en national og international kontekst, forskeren mulighed for at skabe et netværk, der består ikke blot af andre forskere, men også aktive og opsøgende netbrugere (“amatørforskere”), studerende, journalister, forskningsobjekter mv.

Afsluttende er det tankevækkende - som led i en mere generel tendens i udviklingen af websoftware - at konstatere, at bloggen over tid er blevet raffineret som et værktøj, der gennem funktioner såsom kommentarer og "trackback" (visning på bloggen af andre blogs, der linker til ens indlæg) visualiserer og inddrager det netværk, af brugere, der læser bloggen, samtidig med at den som udgangspunkt er et personligt vindue $u d$ mod verden og som sådan også en 
form for værktøj til personlig branding. De mange forskellige former for det såkaldte sociale software (der ifølge en af frontpersonerne inden for genren, Clay Shirky (2003), er alle former for software, der "støtter kommunikation i en gruppe”) er, ud over det sociale sigte, typisk kendetegnet ved, at softwaren giver mulighed for at skabe en personlig profil, der fortæller om alt fra demografiske og fysiske data til ens interesser og tanker (et lokalt eksempel er det danske Groupcare-værktøj). Bloggen, der også regnes i kategorien socialt software, er et interessant eksempel på, at man i kommunikationen af egen identitet og "ansigt” på nettet ser en sammensmeltning mellem personlig markedsføring og social interaktion og netværksvedligeholdelse. Vi er, hvordan vi kommunikerer til og med andre, vi er hvem der linker og læeser os, og vi er med til at skabe andre som personbrands ved at læse og linke til dem. Bloggen er og kan derfor være både en del af ens ”formidlingsportefølje” og web-tilstedeværelse og en dynamisk måde at netværke på i en netværket verden.

\section{Litteratur}

Blood, Rebecca: The Weblog Handbook. Perseus Publishing, 2002.

Boyd, Stove: “Are You Ready for Social Software?” Darwin Magazine, maj 2003. Online: $<$ http://www.darwinmag.com/read/050103/social.html>. (Læst: 03.02.2005).

Mortensen, Torill \& Jill Walker: "Blogging thoughts: personal publication as an online research tool," in: Researching ICTs in Context, ed. Andrew Morrison, InterMedia Report, 3/2002, Oslo 2002. Online: <http://www.intermedia.uio.no/konferanser/skikt02/docs/Researching_ICTs_in_context-Ch11-Mortensen-Walker.pdf> (Læst: 01.02.2005).

Nardi, B., Schiano, D., Gumbrecht, M., Swartz, L. "Why we blog". Communications of the ACM. 47.12 (2004), 41-46. Tidligere udgave tilgængelig på: <http://www.ics.uci.edu/ jpd/classes/ics234cw04/nardi.pdf>. (Læst 03.02.2005).

Shirky, Alan: " Social Software and the Politics of Groups”, <http://shirky.com/writings/group_politics.html>. Først publiceret online 09.03.2003. (Læst: 03.02.2005).

\section{Web-steder}

I forbindelse med arbejdet på denne artikel er påbegyndt en liste over aktive danske forskerweblogs. Den kan findes på: http://www.klastrup.dk/forskerblogs/

En liste over danske weblogs kan findes på: http://spontek.dk/weblogliste.htm 